\title{
Providing the ethical example
}

By: Michael A. Crumpton

Michael A. Crumpton, (2012) "Providing the ethical example", Bottom Line: Managing Library Finances, The, Vol. 25 Iss: 2, pp.49 - 52

Made available courtesy of Emerald Publishing:

http://www.emeraldinsight.com/journals.htm?issn=0888-045X

\begin{abstract}
***Reprinted with permission. No further reproduction is authorized without written permission from the Emerald Publishing. This version of the document is not the version of record. Figures and/or pictures may be missing from this format of the document.***
\end{abstract}

\begin{abstract}
:
Purpose - This paper aims to discuss the importance of maintaining an ethical point of view especially in times of economic uncertainty.

Design/methodology/approach - This paper presents some definitions of ethical behavior and reminds the reader of the consequences of not following an ethical course of action.
\end{abstract}

Findings - From current literature, ethical behaviors have been compromised in some industries, as libraries establish themselves in a new economy it is important to consider revisiting organizational training needs regarding ethics.

Originality/value - This paper is a reminder that regardless of economical situations, proper ethical behavior should be applied.

\section{Article:}

The last couple of years have been tough on budgets which has created hardships for Libraries on numerous fronts including maintaining collections and staffing, investing in new technologies and rewarding people for their efforts. Current financial situations are across the board with some library organizations still cutting budgets, while others have started to build back, although at a reduced level. Can it be said that with the turmoil budgets and budget processes have been put through that we have still maintained an ethical point of view in servicing our target communities?

Ethics is a system of moral principles and values that help establish appropriate conduct for both individuals and organizations. Ethics can be important for many reasons over lots of issues such as; privacy and identity protection, hiring practices, censorship, equality, safety, harassment, to name a few. A deviation from maintaining good ethical behaviors can have disastrous results, one of the most famous being the story of Enron.

In business, ethics is about managing risks as an organization, no matter what individual beliefs or standards are. The risks to library organizations can be many, for example; cutting payroll that impact service options, eliminating segments of the collection, changing formats, reducing or 
modifying staff or staff responsibilities, to identify several. But when decisions have to be made, and something has to be affected, how do you make those ethical decisions? And keep in mind ethics is not synonymous with legal issues, unethical actions can still be deemed legal.

Librarianship is also undergoing a redefinition of itself as the proprietor of information or access to knowledge that will continue to move society forward. Many libraries are already emerging from this economic downturn, different, based on decisions that were made and reactions to financial considerations pressed upon administrators. Do ethics play a part in this struggle over finances and are library leaders setting an ethical example for others to follow as each organization within the profession encounters change?

Ethics is defined by behaviors exhibited, either personally or as an organizational culture which represents the principles that an organization values. Topics impacted by ethics can include fairness and justice, conflicts of interest, use of information and professional responsibility. Many ethical situations are related to people and people that work for the organization; the Society of Human Resource Management (SHRM) not only has its own Code of Ethics for its profession but most HR departments can assist other organizations with the training and development needed to create one of its own.

As libraries emerge from hardship or continue to struggle over organizational reshaping, it is important to have an ethical alignment in how the organization strategically positions itself. ALA's code of Ethics is intended to provide a general guideline of principles and values that are specific to libraries. These principles and values will help create the framework for ethical behaviors during changes made over time or with decisions that impact the financial stability of the library.

\section{The importance of ethical leadership}

Leading results ethically is critical for the development of a healthy organization. A research study conducted by Michael Brown and Linda Trevino from The Pennsylvania State UniversityErie in 2006 provides comprehensive research on the intersection of leadership and ethics. They define ethical leadership as the demonstration of normatively appropriate conduct through personal actions and interpersonal relationships, and the promotion of such conduct to followers through multiple communication techniques. Thus an ethical leader is seen as honest and trustworthy, fair and principled and someone who cares about people and the broader society. But more importantly they address the impact such leaders have on others through social learning theory and how most individuals learn ethics by paying attention and emulating the ethical behaviors of their leaders.

Library leadership must use the ALA Code of Ethics to support and model behaviors and attitudes that can be impacted by questions of morality such as right or wrong, good and bad, justice and virtue. And when circumstances or situations warrant actions not covered by ALA, perhaps development of a customized Code of Ethics is appropriate to the situation, this is also an important component of ethical leadership, recognizing when personalization is needed. 
Regarding leaders, Brown and Trevino discussed many leadership types but one in particular applies to the current situation within the library professional and that is transformational leadership and how ethics impacts this type of leader. Transformational leadership is moral leadership in which leaders inspire their followers to look beyond self-interest and work together for a collective purpose. Tough times and the need for even tougher decisions dictate the need for leaders who are not only transformational but ethical as well.

\section{Do we need more training?}

As mentioned earlier, SHRM not only has its own Code of Ethics but helps other organizations and professions develop their own as well as provide training for ethics and addressing ethical issues. One of the key components of SHRM's toolkit, linked below, is training, for both new hires and incumbents as well as recognizing the need to train on standards that are impacted by a changing environment. Kendrick and Leaver in an article last year titled, "Impact of the code of ethics on workplace behavior in academic libraries", addressed the need for more attention given to ethics education in library schools. Specifically they considered how once librarians are in the workplace, do they act ethically or not and if they do not why not. They also speculated on the impact of an academic librarian making an ethical difference to the larger organization.

Do we as a professional talk enough about ethical issues in order to give new librarians and librarians, and paraprofessionals, who want to be leaders the incentive to become ethical role models or leaders? As the profession struggles with identity issues, ROI and justification claims as well and intellectual property and freedom issues, we must continue to see training and professional development regarding ethics as an important part of a continuous learning environment.

\section{Other perspectives on ethics}

Moya K. Mason in her paper titled, "Ethics of librarianship: libraries, intellectual freedom, and censorship in the age of technology", calls for an increase in attention to workplace ethics as technology has driven librarians into new territories of content and accessibility. And Sarah Glassmeyer writes in her blog, The Ethical Librarian, http://sarahglassmeyer.com/?p=342 about the need to elevate ethical standards in an era of more complications and higher level ethical issues.

In November of 2010, OCLC sponsored a webinar titled, The Ethics of Innovation: Navigating Privacy, Policy, and Service Issues, with main speakers Liza Barry-Kessler and Gary Price. The point was made that we've moved from managing information in self-contained building with only physical items to spreading beyond the walls of any building with technological innovation to create a more complicated world of online content. This means that ethical and legal issues have multiplied considerably from traditional relationships with patrons, vendors, etc. Perhaps it is time to revisit ethical standards to reflect a more complicated and technological advanced set of circumstances.

And finally, David Lankes discusses ethics with regard to participatory librarianship in his article, "The ethics of participatory librarianship". Lankes defines participatory librarianship as 
librarians creating knowledge through conversation which raises the issue of librarians must act in an ethical manner but also are transparent in their ethical believes as they engage in those conversations. This compares private knowledge with public information and an awareness of the biases that can taint the exchange should be of an ethical consideration.

These different perspectives demonstrate the need to broaden our ethical point of view to include a new interruption to older or existing frames of references or current code of ethics standards being followed.

\section{Conclusions and recommendations}

Libraries have spent the past several years' tightening their belts and making decisions based on an unstable economy. This made for an out pouring of emotions-based activities to preserve the level and quality of collections and services. In the process of this upheaval, ethical issues could have been stretched or forgotten and now that things could be looking better, or at least stable financially, it is time to revisit organizational values and customize ethical standards for these new organizations.

As a profession, librarians and staff are encountering new opportunities that can lead to unethical practices, sometimes without even knowing that it is happening. And organizations that emerge from a down economy with much less than they started with, are different and will have different ethical issues to consider.

Look at your organization and the individuals who represent it and make it function. Brainstorm the issues that you now face to see if they fit under any established Code of Ethics, such as ALA's. Create or supplement the standards and values that are not covered and make sure everyone is on board to foster an environment that is ethically sound, including providing ongoing training. Engage your HR department for help if needed. Set an example that will promote a healthy and sustainable organizational environment.

\section{Further Reading}

Brown, M.E., Trevino, L.K. (2006), "Ethical leadership: a review and future directions", The Leadership Quarterly, Vol. 17 No.6, pp.595-616.

Ethical Business (2009), DK Publishing, London, .

Kendrick, K.D., Leaver, E. (2011), "Impact of the code of ethics on workplace behavior in academic libraries", Journal of Information Ethics, Vol. 20 No.1, pp.595-616.

Lankes, D. (2008), "The ethics of participatory librarianship", Journal of Library Administration, Vol. 47 No.3-4, pp.233-41.

Mason, M.K. (2012), "Ethics of librarianship: libraries, intellectual freedom, and censorship in the age of technology", available at: www.moyak.com/papers/ethics-librarianship.html, . 
SHRM (n.d.), "Introduction of ethics and sustainability", available at: www.shrm.org/TemplatesTools/Toolkits/Pages/IntrofEthicsandSustainability.aspx, . 